\title{
Osteosarcoma: Current status of immunotherapy and future trends (Review)
}

\author{
KANJI MORI ${ }^{1,2}$, FRANÇOISE RÉDINI ${ }^{1}$, FRANÇOIS GOUIN ${ }^{1}$, \\ BERTRAND CHERRIER $^{1}$ and DOMINIQUE HEYMANN ${ }^{1}$ \\ ${ }^{1}$ Université de Nantes EA 3822; INSERM ERI 7, Physiopathologie de la Résorption Osseuse et Thérapie \\ des Tumeurs Osseuses Primitives, Faculté de Médecine, 1 rue Gaston Veil, 44035 Nantes cedex 1, France; \\ ${ }^{2}$ Department of Orthopaedic Surgery, Shiga University of Medical Science, Tsukinowa-cho, Seta, \\ Otsu, Shiga 520-2192, Japan
}

Received September 9, 2005; Accepted November 16, 2005

\begin{abstract}
Osteosarcoma is the most common primary bone tumor and represents a major therapeutic challenge in medical oncology. While the use of aggressive chemotherapy has drastically improved the prognosis of the patients with nonmetastatic osteosarcomas, the very poor prognosis of patients with metastasis have led to the exploration of new, more effective and less toxic treatments, such as immunotherapy for curing osteosarcoma. Compared to the numerous reports describing successful immunotherapy for other solid tumors, the number of reports concerning immunotherapy for osteosarcoma is low. However, this therapeutic strategy opens new areas for the treatment of osteosarcoma. In this review, the reasons for delay and all elements essential to develop immunotherapy concerning osteosarcoma are defined. Several pieces of evidence strongly support the potential capability of new therapies such as cellular therapy and gene therapy to eradicate osteosarcoma. Thus, clinical human trials using peptides, cytokines and dendritic cells have been performed. Tumor-infiltrating lymphocytes and some tumor antigens have been identified in osteosarcoma and resulted in an important breakthrough in cellular immunotherapy. Also, RANKL/RANK/OPG, the key regulator of bone metabolism, is a hot spot in this field as therapeutic tools. Immunotherapy for osteosarcomas has great potential, promising improvement in the survival rate and better quality of life for the patients.
\end{abstract}

\section{Contents}

1. Introduction

\footnotetext{
Correspondence to: Dr Kanji Mori, Université de Nantes EA 3822, INSERM ERI 7, Physiopathologie de la Résorption Osseuse et Thérapie des Tumeurs Osseuses Primitives, Faculté de Médecine, 1 rue Gaston Veil, 44035 Nantes cedex 1, France

E-mail: kanchi@belle.shiga-med.ac.jp
}

Key words: osteosarcoma, immunotherapy, bone metabolism, apoptosis
2. Therapeutic strategies based on passive immunity also named adoptive immunity

3. Therapeutic strategies based on active immunity

4. Summary and future trends

5. Conclusion

\section{Introduction}

Osteosarcoma, the most frequent primary bone tumor, typically affects children and young adults (1). The overall survival with an aggressive chemotherapy regimen before and after surgery now varies between 50 and $65 \%$ (2). These poor results have led to the exploration of new, more effective and less toxic treatments, such as immunotherapy for curing osteosarcoma.

Immunotherapy is a therapeutic strategy based on the upregulation of the immune response in tumor-bearing hosts. Two immunotherapy types exist: i) passive or adoptive immunotherapies consist of the administration of ex vivoexpanded tumor-specific cytotoxic immune cells especially $\mathrm{T}$ lymphocytes, ii) active immunotherapies including pulsed dendritic cells and cytokine treatments that elicit immune response against tumor cells. Several reports have strongly underlined the potential interest of these new therapies applicable to osteosarcomas. We summarized the pathway of the representative immunotherapy for osteosarcoma in theme (Fig. 1). This review focuses on the current knowledge as well as the future trends of immunotherapies for osteosarcomas.

\section{Therapeutic strategies based on passive immunity also named adoptive immunity}

Cytotoxic T lymphocytes (CTL) specifically recognizing tumor cells are the pivot cells of passive immunotherapies. Monoclonal, polyclonal and cell lines of $\mathrm{T}$ lymphocytes have already been envisaged to develop such therapeutic strategies.

Tumor antigens inducing HLA class I-restricted tumorspecific cytotoxic T lymphocytes (CTL). The identification of human cancer antigens restricted to HLA class I opened a new area of antigen-specific cancer immunotherapy 
specifically targeting these antigens (3). Specific immunotherapies utilizing peptides deriving from these antigens are ongoing for the treatment of HLA-A1+ patients suffering from melanoma and resulted in major clinical responses $(4,5)$. Based on these observations, this therapeutic strategy was extended to other malignant tumors including osteosarcoma. Indeed, several tumor antigens: melanomaassociated antigen (MAGE) (6), squamous cell carcinoma antigen recognized by T cells (SART) 1 (7), SART3 (8) and papillomavirus binding factor (9) are expressed in osteosarcoma and provided the rationale to develop cellular therapies in osteosarcoma. A newly defined tumor-rejection antigen SART3 is highly expressed in osteosarcoma (8). SART3 was identified from eosophageal cancer cells KE4 (10). The SART3-derived peptides were able to induce HLAA2-restricted and tumor-specific CTL in various histological types (squamous cell carcinoma, astrocytoma and adenocarcinoma) (11). These facts support the potential use of the SART3-derived peptides for specific immunotherapy of HLA-A2+ patients suffering from osteosarcoma. SART3derived peptides induce the production of SART3-specific CTL in an HLA-A24-restricted manner in osteosarcoma (8). Taken together with the prevalence of HLA-A24 (12), this strategy could be applicable for $\sim 60 \%$ of HLA-A24+ patients with osteosarcoma. Furthermore, no severe adverse response associated with peptide administration and a significant upmodulation of the cellular immune response against tumor cells in clinical trial using SART3-derived peptides in HLAA24+ patients with colon cancer (13) encourages further application of this strategy for osteosarcoma.

Polyclonal tumor-infiltrating lymphocytes (TIL): Selected immunotherapeutic weapon that directly induces apoptosis in cancer cells. An immunohistochemical study revealed infiltration of osteosarcomas by T lymphocytes (14). Phenotypic analyses demonstrated that these infiltrating lymphocytes were $95 \% \mathrm{CD} 3+$ and $68 \% \mathrm{CD} 8+(14)$. Rivoltini et al have also performed phenotypic analyses of TIL in 37 pediatric tumors, including 12 osteosarcomas and revealed their CD8+ predominancy (15). It is theorized that the infiltrating lymphoid represents a selected population of cells which have preferentially migrated to the tumor secondary to an immune response. These $\mathrm{T}$ lymphocytes termed TIL are considered to be more specific in their immunological reactivity to tumor cells than the non-infiltrating lymphocytes (16). Thus, the identification of tumor-specific lymphocytes has resulted in new therapeutic strategies based on mounting a sustained and effective anti-tumor immune response $(16,17)$. Recently, we have shown that only TIL extracted from osteosarcoma were cytotoxic against allogeneic tumor cells in the analyses of 27 human patients with boneassociated tumors (osteosarcoma, Ewing's sarcoma, giant cell tumor, chondrosarcoma, plasmocytoma and bone metastases) (18). Furthermore, TIL lytic activity was significantly higher compared to autologous peripheral blood leukocytes. Moreover, TIL extracted from rat osteosarcoma were very sensitive to the tumor antigens expressed by autologous tumor cells and demonstrated increased proliferation (18). These findings strongly support the potential capability of TIL therapy for osteosarcoma.
Rivoltini et al reported in 1992, that TIL obtained from pediatric patients were difficult to use for immunotherapy at required levels (15); however, recent in vitro culture methods have shown great advances. Now, one of the most important conditions of $\mathrm{T}$ cell immunotherapy is their anergic/tolerant manner against tumor cells (19). It has been reported that the Fas-mediated apoptosis pathway plays a crucial role in this condition $(19,20)$; however these poor immune responses could be normalized upon in vitro culture $(21,22)$. Furthermore, immunotherapy combinations with chemotherapeutic agents induce an anti-tumor effect for Fas-mediated apoptosis resistant tumors (23-25). Moreover, interferon (IFN)- $\gamma$ sensitizes osteosarcoma cells to Fas-induced apoptosis through up-regulation of the Fas receptor (26). Combined immunotherapy with IFN- $\gamma$ and either anti-Fas monoclonal antibody or CTL bearing Fas ligand (FasL) might be useful. Thus, TIL remain a viable arm of immunotherapy for osteosarcoma similar to clinical phase II trials in melanoma $(27,28)$.

Except for tumor immune escape in osteosarcoma, the Fas/ FasL pathway plays a crucial role in chemotherapy-induced apoptosis (25) and metastasis $(26,29,30)$. Thus, this pathway was used as a therapeutic target in several strategies $(31,32)$. Mainly, osteosarcoma patients die from lung metastasis; therefore Fas/FasL may be a good therapeutic target, especially as a lung metastasis inhibitor.

Another important factor of T cell therapy is the immunological specificity of $\mathrm{T}$ cells for the tumor $(19,33)$. One approach is to use ex vivo-expanded $\mathrm{T}$ cell clones demonstrating specific lysis of an antigen-positive tumor target. As shown in phase-I study in metastatic melanoma, several advantages of $\mathrm{T}$ cell clone strategy were demonstrated without sever toxic side effects $(5,34,35)$. This $\mathrm{T}$ cell clone strategy will be able to achieve more effective and less toxic $\mathrm{T}$ cell therapy for osteosarcoma.

Natural killer (NK) cells and T cell lines: The cell populations specifically directed against tumor cells. NK cells have innate anti-tumor functions upon tumor regression (36). TALL104 is endowed with MHC non-restricted killer activity against a broad range of tumors across several species, sparing cells from normal tissues (37). TALL-104 cells were administered systemically in an adjuvant setting to 23 cases of canine osteosarcoma after surgery and chemotherapy (38). This therapy achieved favorable median survival times and disease-free intervals compared with canine osteosarcoma treated with standard therapy, and supported the efficacy of adjuvant TALL-104 cell administration. In this series, severe side effects including TALL-104 cell-induced leukemia were not observed, thus this strategy could be worthwhile also in humans.

To up-regulate NK cell-mediated anti-tumor function, certain strategies have been envisaged (cytokines are mentioned below). Kubista et al reported that hyperthermia increases the susceptibility of osteosarcoma cells to NKmediated lysis by increased expression of heat shock proteins (hsp) 72 (39). Hsp 72, implicated in tumor immunity (40), is involved in the interaction between $\mathrm{T}$ lymphocytes and hsp72+ osteosarcoma cells (41). 

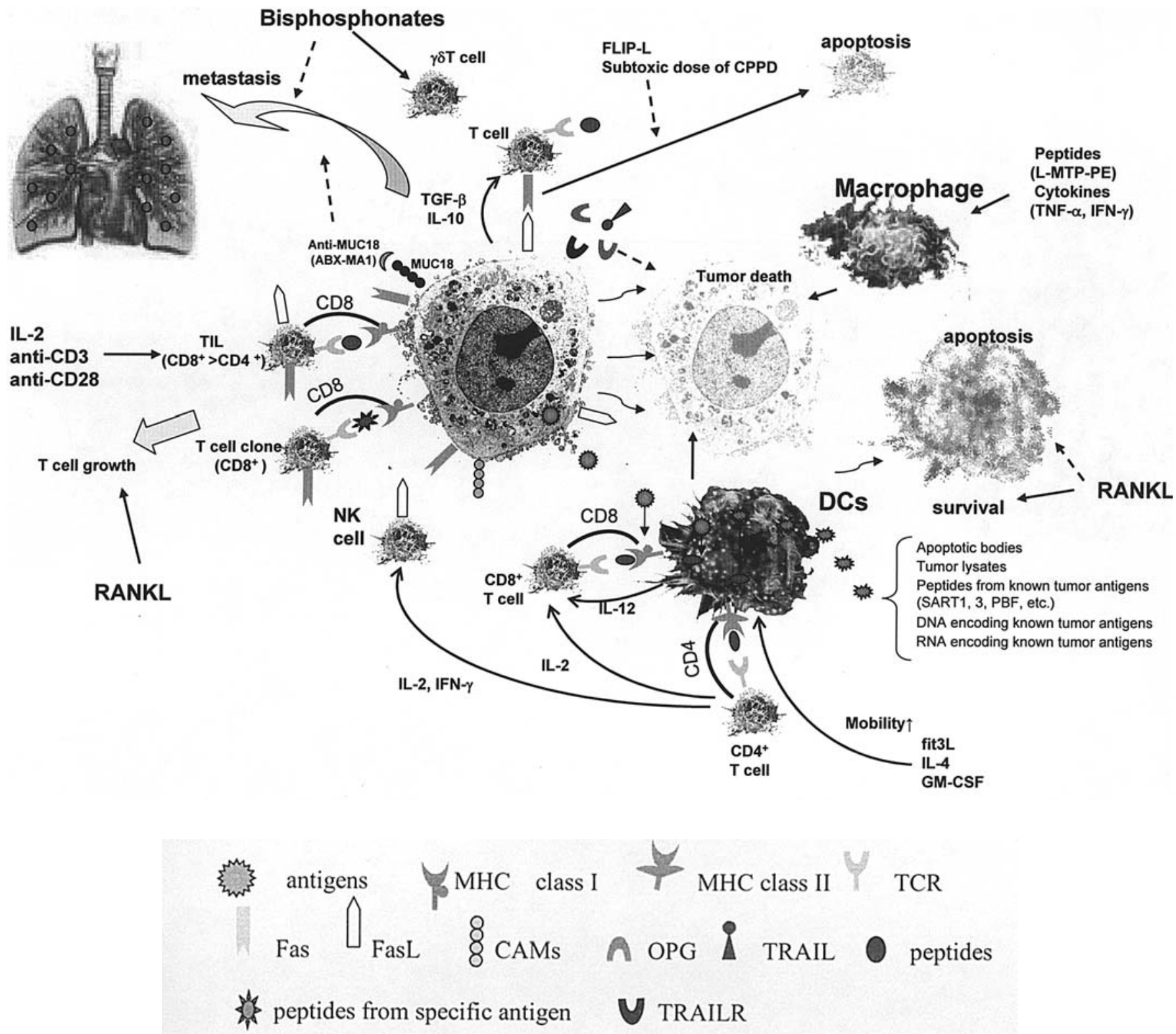

Figure 1. Potential immunotherapeutic approaches against osteosarcoma cells. T cells such as TIL and NK cells directly attack tumor cells in an MHCrestricted manner or not, according to their populations. Administration of DCs induces up-regulation of T cells by presenting peptides in an MHC-restricted manner and also directly targets tumor cells. For priming DCs, several strategies were identified. Cytokine networks stimulate immune therapeutic cells. Administration of peptides (L-MTP-PE) and cytokines (TNF- $\alpha$, IFN- $\gamma$ ) stimulate macrophages. Bisphosphonates have potential anti-tumor effects as metastasis inhibitors and modulate immune response as $\gamma \delta \mathrm{T}$ cell activators. RANKL cannot only prolong the survival time of DCs, but also induce T cell growth. OPG acts as a decoy receptor of TRIL. CAMs, cell adhesion molecules; CDDP, cisplatin; DCs, dendritic cells; fit3L, fit3 ligand; FLIP-L, FLICE inhibitory protein long form; FasL, Fas ligand; GM-CSF, granulocyte macrophage-colony stimulating factor; IFN, interferon; IL, interleukin; L-MTP-PE, liposome-encapsulated muramyl tripeptide phosphatidylethanolamine; RANKL, receptor activator of nuclear factor- $\mathrm{B}$ ligand; OPG, osteoprotegerin; PBF, papillomavirus binding factor; SART1, 3, squamous cell carcinoma antigen recognized by T cells 1,3 ; TCR, T cell receptor; TGF- 3 , transforming growth factor- $\beta$; TIL, tumor-infiltrating lymphocytes; TNF- $\alpha$, tumor necrosis factor- $\alpha$; TRAIL, TNF-related apoptosis-inducing ligand; TRAILR, TRAIL receptor; black solid arrow, activation; dotted arrow, suppression.

\section{Therapeutic strategies based on active immunity}

To elicit immunity of tumor-bearing hosts, antigen presenting cells (APCs) such as dendritic cell (DC)-based therapies, cytokine-based therapies and gene therapies have been demonstrated.

Monocyte lineage constitutes a complex system of professional $A P C s$ which can induce primary $T$ and $B$ cell responses. DCs constitute a complex system of professional APCs that have the unique capacity to induce primary $\mathrm{T}$ and $\mathrm{B}$ cell responses
(42). The main pathway of DC-based immunotherapy is to up-regulate lymphocyte activity, such as NK cells and TIL, and the goal will be to optimize the use of DCs (i.e., vaccination) in maintaining $\mathrm{T}$ lymphocyte survival and specificity. A number of clinical trials are currently underway studying DCs in a variety of tumors (43). One clinical phase-I study using DCs against solid tumors in children including osteosarcoma has been reported (44). In this series, one patient with metastatic fibrosarcoma demonstrated strong positive response without obvious toxic side effects. Some relevant topics include antigen loading and DC maturation procedures, 
frequency and route of DC administration, efficacy of DCs homing to lymphoid tissues and their durability once there and the role of distinct DC subsets $(42,43)$.

Monocyte/macrophage-mediated tumor cell killing is a major mechanism of the hosts' defense against primary and/or metastatic neoplasms. Liposome-encapsulated muramyl tripeptide phosphatidylethanolamine (L-MTP-PE) is a peptide that acts as a potent activator of monocytes/macrophages in humans, mice and dogs (tumor antigen-derived peptides used to produce T cells in vitro or to charge DCs). In over $125 \mathrm{dogs}$ with osteosarcoma, L-MTP-PE was found to prolong metastasis-free and overall survival rates when given alone or after systemic chemotherapy $(45,46)$. Kurzman et al reported that canine pulmonary alveolar macrophages from dogs treated with doxorubicin (DOX) + L-MTP-PE have enhanced cytotoxic activity against osteosarcoma cells when compared to dogs treated with DOX or L-MTP-PE alone (47). These findings support the rationale for combining chemotherapy agents with immunotherapy for the treatment of metastatic disease. The greater anti-tumor activity of L-MTP-PE has been also demonstrated in children with metastatic osteosarcoma and a phase-III randomized trial has been started $(48,49)$.

Cytokines: most widely used and investigated, possibly essential molecules in immunotherapy due to their excellent wide range ability. Cytokines represented by interleukins (ILs) play a crucial role in the expression of cellular adhesion molecules (CAMs) and the function of anti-tumor effector cells as the most potent modulators of the immune responses. CAMs play an important role in immune responses including NK cell binding to target (50). Indeed, melanoma CAM, synonymous MUC18 plays a crucial role in osteosarcoma metastasis (51). Osteosarcoma cells express this molecule and ABX-MA1, a fully human anti-MUC18 antibody, inhibited the metastasis of human osteosarcoma cells in vivo (51). The most widely studied IL in this field is IL-2 (52). Luksch et al have reported a clinical trial in osteosarcoma using IL-2 (53), in which 18 children with localized osteosarcoma received four IL-2 courses $\left(9 \times 10^{6} \mathrm{IU} / \mathrm{ml} /\right.$ day $\mathrm{x} 4)$, alternated with pre- and post-operative multiple chemotherapies. The results showed that intensive chemotherapies have no effect on the IL-2-induced immune activation, and suggested a role of the NK cells in the control of osteosarcoma. On the contrary, it has been reported that the clinical use of IL-2 is limited by the significant toxic side effects caused by the administration of this cytokine in doses sufficient for cell activation in vivo (54). Other ILs have been recognized as candidates for human immunotherapy. Some studies using IL-12 (55), IL-12 associated with IL-18 (56), IL-18 (57) and IL-17 (58) in osteosarcoma have already been performed. These cytokine-based therapies demonstrated enhanced cytotoxic activity of T cells in osteosarcoma. Also, it has been reported that tumor necrosis factor (TNF)- $\alpha$ and IFN- $\gamma$ can induce the anti-tumor activity of macrophages (47).

Gene therapy eliciting immune response in tumor-bearing hosts represents one option of immunotherapy. In the field of gene therapy for osteosarcoma, several approaches have been envisaged, such as the suicide gene therapy $(59,60)$, tumor- suppressor gene therapy (61-64) and cytokine-based gene therapy (65-68). The most investigated gene transfer vector is the adenoviral vector (Adv) (69). A single injection of Advencoding IL-2 gene (Ad IL-2) into a primary tumor lesion elicited anti-tumoral immunity and this immunity not only suppressed primary tumor growth but also eradicated disseminated micro-metastases in distant organs (70). In this study, not only minimal side effects but also maximal therapeutic effects were exerted only in the case of injecting the optimal dose (not the highest) of Ad IL-2. Important limitations in this regard are the failure of non-replicating Adv to achieve sufficient tumor-cell transduction and effective solid-tumor penetration. Furthermore, the expression of coxackievirus and adenovirus receptor, which is an important determining factor for adenoviral gene transfer efficiency, in osteosarcoma is controversial (71-73). Witlox et al demonstrated that targeting a conditionally replicative adenovirus toward integrins Ad5- $\triangle 24 \mathrm{RGD}$, providing alternative viral entry pathway, greatly enhances its cytotoxicity on osteosarcoma and warrants further exploration of Ad5- $\Delta 24 R G D$ for its utility in osteosarcoma treatment (74). However, the fetal case report following adenovirus gene transfer (75) indicated against this strategy in humans. As other than adenovirus gene transfer vectors, it has been shown that osteosarcoma cell lines were good targets for lentiviral transduction with favorable gene transfer efficiency $(76,77)$. After the development of a successful and safe delivery of the therapeutic gene, this strategy demonstrates great potential activity to modulate the prognosis of patients with osteosarcoma.

\section{Summary and future trends}

There is no doubt that one of the most significant advances in the field of anti-cancer therapy has been the recent development of immunotherapy; however, the initial results of human trials were not realized as expected. The reasons for this discrepancy have been reported $(19,78)$. It is now common knowledge that the tumor burden contributes to a significant suppressive environment. Thus, surgery remains the first line for debulking tumors and radiation and/or chemotherapy can be used for the removal of remaining and micro-metastatic lesions as well as reducing tumor burden. To achieve desired results, immunotherapies combined with these conventional treatments are recommended.

The number of published data of immunotherapy for bone tumors is very low compared with that of other solid tumors. The reasons for this delay were discussed $(9,79)$ and the following points were raised; i) the relatively low immunogenicity of osteosarcoma as only few examples of spontaneous tumor regression exist $(80,81)$, ii) the practical difficulty in establishing osteosarcoma cell lines and autologous CTL $(82,83)$ and iii) the lack of suitable candidate genes for a reverse immunological approach such as a tumorspecific fusion gene $(84,85)$. However, another hopeful explanation of this delay resides in environmental factors peculiar to bone. Recent studies have clarified molecules, such as the receptor activator of nuclear factor- $\mathrm{\kappa}$ ligand (RANKL)/RANK/osteoprotegerin (OPG) as the key regulators of normal and pathological bone metabolism (86-90). 
Thus, correlations between the phenotypes of the tumors and changes of RANKL/OPG have been reported (91). In osteosarcoma, high OPG $(92,93)$ and lack of RANKL at the mRNA level (94) have been reported. To prevent bone destruction due to malignancies, the potential capability of these molecules as therapeutic tools has been suggested (95). As osteoclast is the unique cell that can induce bone degradation, inactivation of the osteoclast by OPG was targeted. Honore et al have reported that the administration of OPG blocked bone cancer-induced skeletal destruction (96). Furthermore, direct effects of RANKL/RANK/OPG on immune response were reported. Specifically, RANKL can dramatically inhibit DC apoptosis via increased Bcl-xL expression (97) and induce T cell growth (98). OPG acts as a weak decoy receptor for TNF-related apoptosis-inducing ligand (TRAIL) (99) and modulates tumor apoptosis (100). Also, bisphosphonates (BPs) can be another therapeutic approach for osteosarcoma. Except for known function of BPs, the inhibitory effects of BPs on the metastases as well as the potent anti-cancer effect have been suggested (101). Moreover, as BPs can activate $\gamma \delta \mathrm{T}$ cells involved in tumor cell surveillance and killing (102), the ability of BPs as $\gamma \delta \mathrm{T}$ cell activators is encouraging for immunotherapy. These results provide the rational to use the molecules in immunotherapy for osteosarcoma; however, the safe administration of these agents in humans should be addressed carefully.

\section{Conclusion}

To date, the number of published clinical trial of immunotherapy for osteosarcoma is low. However, there are several pieces of evidence strongly supporting the potential capability of immunotherapy to eradicate osteosarcoma in combination with conventional treatment. Immunotherapy for osteosarcomas has potential promising improvement in the survival rate and better quality of life for patients with this tumor.

\section{Acknowledgements}

This study was partially supported by grants from Uehara Memorial Foundation and Kanae Foundation for Life \& Socio-Medical Science, and also supported by a grant from the Association pour la Recherche contre le Cancer (ARC) No. 3561.

\section{References}

1. Renard AJ, Veth RP, Schreuder HW, Pruszczynski M, Bokkerink JP, van Hoesel QG and van Der Staak FJ: Osteosarcoma: oncologic and functional results. A single institutional report covering 22 years. J Surg Oncol 72: 124-129, 1999.

2. Bacci G, Briccoli A, Ferrari S, Longhi A, Mercuri M, Capanna R, Donati D, Lari S, Forni C and De Paolis M: Neoadjuvant chemotherapy for osteosarcoma of the extremity. Long-term results of the Rizzoli's 4th protocol. Eur J Cancer 37: 2030-2039, 2001.

3. Rosenberg SA: Progress in human tumour immunology and immunotherapy. Nature 411: 380-384, 2001.

4. Nestle FO, Alijagic S, Gilliet M, Sun Y, Grabbe S, Dummer R, Burg G and Schadendorf D: Vaccination of melanoma patients with peptide- or tumor lysate- pulsed dendritic cells. Nat Med 4: 328-332, 1998
5. Rosenberg SA, Yang JC, Schwartzentruber DJ, et al: Immunologic and therapeutic evaluation of a systemic peptide vaccine for the treatment of patient with metastatic melanoma. Nat Med 4: 321-327, 1998.

6. Sudo T, Kuramoto T, Komiya S, Inoue A and Itoh K: Expression of MAGE genes in osteosarcoma. J Orthop Res 15: 128-132, 1997.

7. Ishida $\mathrm{H}$, Komiya $\mathrm{S}$, Inoue $\mathrm{Y}$, Yutani $\mathrm{S}$, Inoue $\mathrm{A}$ and Itoh $\mathrm{K}$ : Expression of the SART1 tumor-rejection antigen in human osteosarcomas. Int J Oncol 17: 29-32, 2000.

8. Tsuda N, Murayama K, Ishida H, Matsunaga K, Komiya S, Itoh K and Yamada A: Expression of a newly defined tumor-rejection antigen SART3 in musculoskeletal tumors and induction of HLA class I-restricted cytotoxic T lymphocytes by SART3derived peptides. J Orthop Res 19: 346-351, 2001.

9. Tsukahara T, Nabeta Y, Kawaguchi S, et al: Identification of human autologous cytotoxic T-lymphocyte-defined osteosarcoma gene that encodes a transcriptional regulator, papillomavirus binding factor. Cancer Res 64: 5442-5448, 2004.

10. Yang D, Nakao M, Shichijo S, et al: Identification of a gene coding for a protein possessing shared tumor epitopes capable of inducing HLA-A24-restricted cytotoxic T lymphocytes in cancer patients. Cancer Res 59: 4056-4063, 1999.

11. Ito M, Shichijo S, Miyagi Y, Kobayashi T, Tsuda N, Yamada A, Saito N and Itoh K: Identification of SART3-derived peptides capable of inducing HLA-A2-restricted and tumor-specific CTLs in cancer patients with different HLA-A2 subtypes. Int J Cancer 88: 633-639, 2000.

12. Imanishi T, Akazawa T, Kimura A, et al: Allele and haplotype frequencies for HLA and complement loci in various ethnic groups. In: HLA, 1991. Tsuji K, Akizawa M and Sasazuki T (eds). Vol. 1, Oxford Scientific Publications, Oxford, pp1065-1220, 1992.

13. Miyagi Y, Imai N, Sasatomi T, Yamada A, Mine T, Katagiri K, Nakagawa M, Muto A, Okouchi S, Isomoto H, Shirouzu K, Yamana $\mathrm{H}$ and Itoh $\mathrm{K}$ : Induction of cellular immune responses to tumor cells and peptides in colorectal cancer patients by vaccination with SART3 peptides. Clin Cancer Res 7: 3950-3962, 2001.

14. Trieb K, Lechleitner T, Lang S, Windhager R, Kotz R and Dirnhofer S: Evaluation of HLA-DR expression and Tlymphocyte infiltration in osteosarcoma. Pathol Res Pract 194: 679-684, 1998.

15. Rivoltini L, Arienti F, Orazi A, Cefalo G, Gasparini M, Gambacorti-Passerini C, Fossati-Bellani F and Parmiani G: Phenotypic and functional analysis of lymphocytes infiltrating paediatric tumours, with a characterization of the tumour phenotype. Cancer Immunol Immunother 34: 241-251, 1992.

16. Rosenberg SA, Spiess P and Lafreniere R: A new approach to the adoptive immunotherapy of cancer with tumor-infiltrating lymphocytes. Science 233: 1318-1321, 1986.

17. Aebersold P, Hyatt C, Johnson S, Hines K, Korcak L, Sanders M, Lotze M, Topalian S, Yang J and Rosenberg SA: Lysis of autologous melanoma cells by tumor-infiltrating lymphocytes: association with clinical response. J Natl Cancer Inst 83: 932-937, 1991.

18. Théoleyre S, Mori K, Cherrier B, Passuti N, Gouin F, Rédini F and Heymann D: Phenotypic and functional analysis of lymphocytes infiltrating osteolytic tumors: use as a new therapeutic approach of osteosarcoma. BMC Cancer 5: 123, 2005.

19. Zou W: Immunosuppressive networks in the tumour environment and their therapeutic relevance. Nat Rev Cancer 5: 263-274, 2005.

20. O'Connell J, Bennett MW, O'Sullivan GC, Collins JK and Shanahan F: The Fas counter attack: Fas mediated T cell killing by colon cancer cells expressing Fas ligand. J Exp Med 184: 1075-1082, 1996.

21. Chen YM, Yang WK, Whang-Peng J, Tsai WY, Hung YM, Yang DM, Lin WC, Perng RP and Ting CC: Restoration of the immunocompetence by IL-2 activation and TCR-CD3 engagement of the in vivo anergized tumor-specific CTL from lung cancer patients. J Immunother 20: 354-364, 1997.

22. Tartour E, Latour S, Mathiot C, Thiounn N, Mosseri V, Joyeux I, D'Enghien CD, Lee R, Debre B and Fridman WH: Variable expression of CD3-zeta chain in tumor-infiltrating lymphocytes (TIL) derived from renal-cell carcinoma: relationship with TIL phenotype and function. Int J Cancer 63: 205-212, 1995.

23. Frost $\mathrm{P}$ and Bonavida $\mathrm{B}$ : Circumvention of tumor cell escape following specific immunotherapy. Cancer Biother Radiopharmacol 15: 141-152, 2000. 
24. Kinoshita H, Yoshikawa H, Shiiki K, Hamada Y, Nakajima Y and Tasaka K: Cysplatin (CDDP) sensitizes human osteosarcoma cell to Fas/CD95-mediated apoptosis by down-regulating FLIP-L expression. Int J Cancer 88: 986-991, 2000.

25. Duan X, Zhou Z, Jia SF, Colvin M, Lafleur EA and Kleinerman ES: Interleukin-12 enhances the sensitivity of human osteosarcoma cells to 4-hydroperoxycyclophosphamide by a mechanism involving the Fas/Fas-ligand pathway. Clin Cancer Res 10: 777-783, 2004.

26. Inaba H, Glibetic M, Buck S, Ravindranath Y and Kaplan J: Interferon-gamma sensitizes osteosarcoma cells to fas-induced apoptosis by up-regulating fas receptors and caspase- 8 . Pediatr Blood Cancer 43: 729-736, 2004.

27. Labarriere N, Pandolfino MC, Gervois N, Khammari A, Tessier MH, Dreno B and Jotereau F: Therapeutic efficacy of melanoma-reactive TIL injected in stage III melanoma patients. Cancer Immunol Immunother 51: 532-538, 2002.

28. Dreno B, Nguyen JM, Khammari A, Pandolfino MC, Tessier MH, Bercegeay S, Cassidanius A, Lemarre P, Billaudel S, Labarriere N and Jotereau F: Randomized trial of adoptive transfer of melanoma tumor-infiltrating lymphocytes as adjuvant therapy for stage III melanoma. Cancer Immunol Immunother 51: 539-546, 2002.

29. Worth LL, Lafleur EA, Jia SF and Kleinerman ES: Fas expression inversely correlates with metastatic potential in osteosarcoma cells. Oncol Rep 9: 823-827, 2002.

30. Lafleur EA, Koshkina NV, Stewart J, Jia SF, Worth LL, Duan X and Kleinerman ES: Increased Fas expression reduces the metastatic potential of human osteosarcoma cells. Clin Cancer Res 10: 8114-8119, 2004.

31. Imai T, Adachi S, Nishijo K, Ohgushi M, Okada M, Yasumi T, Watanabe K, Nishikomori R, Nakayama T, Yonehara S, Toguchida J and Nakahata T: FR901228 induces tumor regression associated with induction of Fas ligand and activation of Fas signaling in human osteosarcoma cells. Oncogene 22: 9231-9242, 2003

32. Watanabe K, Okamoto $\mathrm{K}$ and Yonehara S: Sensitization of osteosarcoma cells to death receptor-mediated apoptosis by HDAC inhibitors through downregulation of cellular FLIP. Cell Death Differ 12: 10-18, 2005.

33. Yee C, Thompson JA, Byrd D, Riddell SR, Roche P, Celis E and Greenberg PD: Adoptive T cell therapy using antigenspecific $\mathrm{CD} 8+\mathrm{T}$ cell clones for the treatment of patients with metastatic melanoma: in vivo persistence, migration, and antitumor effect of transferred T cells. Proc Natl Acad Sci USA 99: 16168-16173, 2002.

34. Reynolds SR, Celis E, Sette A, Oratz R, Shapiro RL, Johnston D, Fotino $\mathrm{M}$ and Bystryn JC: HLA-independent heterogeneity of CD8+ T cell responses to MAGE-3, Melan-A/MART-1, gp100, tyrosinase, MC1R, and TRP-2 in vaccine-treated melanoma patients. J Immunol 161: 6970-6976, 1998.

35. Thurner B, Haendle I, Roder C, Dieckmann D, Keikavoussi P, Jonuleit H, Bender A, Maczek C, Schreiner D, von den Driesch P, Brocker EB, Steinman RM, Enk A, Kampgen E and Schuler G: Vaccination with mage-3A1 peptide-pulsed mature, monocytederived dendritic cells expands specific cytotoxic $\mathrm{T}$ cells and induces regression of some metastases in advanced stage IV melanoma. J Exp Med 190: 1669-1678, 1999.

36. O'Shea J and Ortaldo JR: The biology of natural killer cells: Insights into molecular basis of function. In: The Natural Killer Cell. Lewis CE and McGee Jo (eds). IRL Press, Oxford, pp2-40, 1992.

37. Cesano A and Santoli D: Two unique human leukemic T-cell lines endowed with stable cytotoxic function and different spectrum of target reactivity. Analysis and modulation of their lytic mechanisms. In Vitro Cell Dev Biol 28: 657-662, 1992.

38. Visonneau S, Cesano A, Jeglum KA and Santoli D: Adjuvant treatment of canine osteosarcoma with the human cytotoxic T-cell line TALL-104. Clin Cancer Res 5: 1868-1875, 1999.

39. Kubista B, Trieb K, Blahovec H, Kotz R and Micksche M: Hyperthermia increases the susceptibility of chondro- and osteosarcoma cells to natural killer cell-mediated lysis. Anticancer Res 22: 789-792, 2002.

40. Castelli C, Rivoltini L, Rini F, Belli F, Testori A, Maio M, Mazzaferro V, Coppa J, Srivastava PK and Parmiani G: Heat shock proteins: biological functions and clinical application as personalized vaccines for human cancer. Cancer Immunol Immunother 53: 227-233, 2004

41. Trieb K, Lang S and Kotz R: Heat-shock protein 72 in human osteosarcoma: T-lymphocytes reactivity and cytotoxicity. Pediatr Hematol Oncol 17: 355-364, 2000.
42. Banchereau J and Palucka AK: Dendritic cells as therapeutic vaccines against cancer. Nat Rev Immunol 5: 296-306, 2005.

43. Steinman RM and Dhodapkar M: Active immunization against cancer with dendritic cells: The near future. Int J Cancer 94: 459-473, 2001

44. Geiger J, Hutchinson R, Hohenkirk L, McKenna E, Chang A and Mule J: Treatment of solid tumours in children with tumour-lysate-pulsed dendritic cells. Lancet 356: 1163-1165, 2000 .

45. Kurzman ID, MacEwen EG, Rosenthal RC, et al: Adjuvant therapy for osteosarcoma in dogs: results of randomized clinical trials using combined liposome-encapsulated muramyl tripeptide and cisplatin. Clin Cancer Res 1: 1595-1601, 1995.

46. MacEwen EG, Kurzman ID, Rosenthal RC, Smith BW, Manley PA, Roush JK and Howard PE: Therapy for osteosarcoma in dogs with intravenous injection of liposomeencapsulated muramyl tripeptide. J Natl Cancer Inst 81: 935-938, 1989.

47. Kurzman ID, Shi F, Vail DM and MacEwen EG: In vitro and in vivo enhancement of canine pulmonary alveolar macrophage cytotoxic activity against canine osteosarcoma cells. Cancer Biother Radiopharm 14: 121-128, 1999.

48. Kleinerman ES, Gano JB, Johnston DA, Benjamin RS and Jaffe N: Efficacy of liposomal muramyl tripeptide (CGP 19835A) in the treatment of relapsed osteosarcoma. Am J Clin Oncol 18: 93-99, 1995

49. Kleinerman ES, Raymond AK, Bucana CD, Jaffe N, Harris MB, Krakoff IH, Benjamin R and Fidler IJ: Unique histological changes in lung metastasis of osteosarcoma patients following therapy with liposomal muramyl tripeptide (CGP 19835A lipid). Cancer Immunol Immunother 34: 211-220, 1992.

50. Koukoulis GK, Patriarca C and Gould VE: Adhesion molecules and tumor metastasis. Hum Pathol 29: 889-892, 1998.

51. McGary EC, Heimberger A, Mills L, Weber K, Thomas GW, Shtivelband M, Lev DC and Bar-Eli M: A fully human antimelanoma cellular adhesion molecule/MUC18 antibody inhibits spontaneous pulmonary metastasis of osteosarcoma cells in vivo. Clin Cancer Res 9: 6560-6566, 2003.

52. Eklund JW and Kuzel TM: A review of recent findings involving interleukin-2-based cancer therapy. Curr Opin Oncol 16: 542-546, 2004.

53. Luksch R, Perotti D, Cefalo G, Gambacorti Passerini C, Massimino M, Spreafico F, Casanova M, Ferrari A, Terenziani M, Polastri D, Gambirasio F, Podda M, Bozzi F, Ravagnani F, Parmiani $G$ and Fossati Bellani F: Immunomodulation in a treatment program including pre- and post-operative interleukin-2 and chemotherapy for childhood osteosarcoma. Tumori 3: 263-268, 2003.

54. Nasr S, McKolanis J, Pais R, Findley H, Hnath R, Waldrep K and Ragab AH: A phase I study of interleukin-2 in children with cancer and evaluation of clinical immunologic status during therapy. Cancer 64: 783-788, 1989.

55. Mariani E, Meneghetti A, Tarozzi A, Cattini L and Facchini A: Interleukin-12 induces efficient lysis of natural killer-sensitive and natural killer-resistant human osteosarcoma cells: the synergistic effect of interleukin-2. Scand J Immunol 51: 618-625, 2000 .

56. Liebau C, Merk H, Schmidt S, Roesel C, Karreman C, Prisack JB, Bojar $\mathrm{H}$ and Baltzer AW: Interleukin-12 and interleukin-18 change ICAM-I expression, and enhance natural killer cell mediated cytolysis of human osteosarcoma cells. Cytokines Cell Mol Ther 7: 135-142, 2002

57. Okamoto T, Yamada N, Tsujimura T, Sugihara A, Nishizawa Y, Ueda H, Kashiwamura S, Tsutsui H, Futani H, Maruo S, Okamura $\mathrm{H}$ and Terada $\mathrm{N}$ : Inhibition by interleukin-18 of the growth of Dunn osteosarcoma cells. J Interferon Cytokine Res 24: 161-167, 2004.

58. Honorati MC, Neri S, Cattini L and Facchini A: IL-17 enhances the susceptibility of U-2 OS osteosarcoma cells to NK cell lysis. Clin Exp Immunol 3: 344-349, 2003

59. Ko SC, Cheon J, Kao C, Gotoh A, Shirakawa T, Sikes RA, Karsenty G and Chung LW: Osteocalcin promoter-based toxic gene therapy for the treatment of osteosarcoma in experimental models. Cancer Res 56: 4614-4619, 1996.

60. Tsuji H, Kawaguchi S, Wada T, Nagoya S, Inobe M, Yagita H, Okumura K, Yamashita T and Uede T: Concurrent induction of T-cell activation and apoptosis of osteosarcoma cells by adenovirus-mediated B7-1/Fas chimeric gene transfer. Cancer Gene Ther 10: 717-725, 2003. 
61. Xu HJ, Zhou Y, Seigne J, Perng GS, Mixon M, Zhang C, Li J, Benedict WF and Hu SX: Enhanced tumor suppressor gene therapy via replication-deficient adenovirus vectors expressing an N-terminal truncated retinoblastoma protein. Cancer Res 56: 2245-2249, 1996.

62. Kim M, Sgagias M, Deng X, Jung YJ, Rikiyama T, Lee K, Ouellette $\mathrm{M}$ and Cowan K: Apoptosis induced by adenovirusmediated p14ARF expression in U2OS osteosarcoma cells is associated with increased Fas expression. Biochem Biophys Res Commun 320: 138-144, 2004.

63. Nakase M, Inui M, Okumura K, Kamei T, Nakamura S and Tagawa T: p53 gene therapy of human osteosarcoma using a transferrin-modified cationic liposome. Mol Cancer Ther 4: 625-631, 2005

64. Hellwinkel OJ, Muller J, Pollmann A and Kabisch H: Osteosarcoma cell lines display variable individual reactions on wildtype $\mathrm{p} 53$ and $\mathrm{Rb}$ tumour-suppressor transgenes. J Gene Med 7: 407-419, 2005.

65. Worth LL, Jia SF, Zhou Z, Chen L and Kleinerman ES: Intranasal therapy with an adenoviral vector containing the murine interleukin-12 gene eradicates osteosarcoma lung metastases. Clin Cancer Res 6: 3713-3718, 2000.

66. Lafleur EA, Jia SF, Worth LL, Zhou Z, Owen-Schaub LB and Kleinerman ES: Interleukin (IL)-12 and IL-12 gene transfer upregulate Fas expression in human osteosarcoma and breast cancer cells. Cancer Res 61: 4066-4071, 2001.

67. Tamura T, Nishi T, Goto T, Takeshima H, Ushio Y and Sakata T: Combination of IL-12 and IL-18 of electro-gene therapy synergistically inhibits tumor growth. Anticancer Res 23: 1173-1179, 2003.

68. Liebau C, Roesel C, Schmidt S, Karreman C, Prisack JB, Bojar H, Merk $\mathrm{H}$, Wolfram $\mathrm{N}$ and Baltzer AW: Immunotherapy by gene transfer with plasmids encoding IL-12/IL-18 is superior to IL23/IL-18 gene transfer in a rat osteosarcoma model. Anticancer Res 24: 2861-2867, 2004.

69. Edelstein ML, Abedi MR, Wixon J and Edelstein RM: Gene therapy clinical trials worldwide 1989-2004-an overview. J Gene Med 6: 597-602, 2004.

70. Nagano S, Yuge K, Fukunaga M, Terazaki Y, Fujiwara H, Komiya S and Kosai K: Gene therapy eradicating distant disseminated micro-metastases by optimal cytokine expression in the primary lesion only: novel concepts for successful cytokine gene therapy. Int J Oncol 24: 549-558, 2004.

71. Gu W, Ogose A, Kawashima H, Ito M, Ito T, Matsuba A, Kitahara H, Hotta T, Tokunaga K, Hatano H, Morita T, Urakawa S, Yoshizawa T, Kawashima H, Kuwano R and Endo N: High-level expression of the coxsackievirus and adenovirus receptor messenger RNA in osteosarcoma, Ewing's sarcoma, and benign neurogenic tumors among musculoskeletal tumors. Clin Cancer Res 10: 3831-3838, 2004.

72. Graat HC, Wuisman PI, van Beusechem VW, Carette JE, Gerritsen WR, Bras J, Schaap GR, Kaspers GJ, Ogose A, Gu W, Kawashima $\mathrm{H}$ and Hotta T: Coxsackievirus and adenovirus receptor expression on primary osteosarcoma specimens and implications for gene therapy with recombinant adenoviruses. Clin Cancer Res 11: 2445-2447, 2005.

73. Feugeas O, Guriec N, Babin-Boilletot A, Marcellin L, Simon P, Babin S, Thyss A, Hofman P, Terrier P, Kalifa C, BrunatMentigny M, Patricot LM and Oberling F: Loss of heterozygosity of the RB gene is a poor prognostic factor in patients with osteosarcoma. J Clin Oncol 14: 467-472, 1996.

74. Witlox AM, van Beusechem VW, Molenaar B, Bras H, Schaap GR, Alemany R, Curiel DT, Pinedo HM, Wuisman PI and Gerritsen WR: Conditionally replicative adenovirus with tropism expanded towards integrins inhibits osteosarcoma tumor growth in vitro and in vivo. Clin Cancer Res 10: 61-67, 2004.

75. Raper SE, Chirmule N, Lee FS, Wivel NA, Bagg A, Gao GP, Wilson JM and Batshaw ML: Fatal systemic inflammatory response syndrome in a ornithine transcarbamylase deficient patient following adenoviral gene transfer. Mol Genet Metab 80: $148-158,2003$

76. Pellinen R, Hakkarainen T, Wahlfors T, Tulimaki K, Ketola A, Tenhunen A, Salonen T and Wahlfors J: Cancer cells as targets for lentivirus-mediated gene transfer and gene therapy. Int J Oncol 25: 1753-1762, 2004.

77. Ketola A, Maatta AM, Pasanen T, Tulimaki K and Wahlfors J: Osteosarcoma and chondrosarcoma as targets for virus vectors and herpes simplex virus thymidine kinase/ganciclovir gene therapy. Int J Mol Med 13: 705-710, 2004.
78. Yannelli JR and Wroblewski JM: On the road to a tumor cell vaccine: 20 years of cellular immunotherapy. Vaccine 23: 97-113, 2004.

79. Ben-Efraim S: Cancer immunotherapy: hopes and pitfalls: a review. Anticancer Res 16: 3235-3240, 1996.

80. Ogihara Y, Takeda K, Yanagawa T and Hirasawa Y: Spontaneous regression of lung metastases from osteosarcoma. Cancer 74: 2798-2803, 1994.

81. Sabate JM, Llauger J, Torrubia S, Amores S and Franquet T: Osteosarcoma of the abdominal wall with spontaneous regression of lung metastases. Am J Roentgenol 171: 691-692, 1998.

82. Nabeta Y, Kawaguchi S, Sahara H, Ikeda H, Hirohashi Y, Goroku T, Sato Y, Tsukahara T, Torigoe T, Wada T, Kaya M, Hiraga H, Isu K, Yamawaki S, Ishii S, Yamashita T and Sato N: Recognition by cellular and humoral autologous immunity in a human osteosarcoma cell line. J Orthop Sci 8: 554-559, 2003.

83. Slovin SF, Lackman RD, Ferrone S, Kiely PE and Mastrangelo MJ: Cellular immune response to human sarcomas: cytotoxic $\mathrm{T}$ cell clones reactive with autologous sarcomas. I. Development, phenotype, and specificity. J Immunol 137: 3042-3048, 1986.

84. Sato Y, Nabeta Y, Tsukahara T, Hirohashi Y, Syunsui R, Maeda A, Sahara H, Ikeda H, Torigoe T, Ichimiya S, Wada T, Yamashita T, Hiraga H, Kawai A, Ishii T, Araki N, Myoui A, Matsumoto S, Umeda T, Ishii S, Kawaguchi S and Sato N: Detection and induction of CTLs specific for SYT-SSX-derived peptides in HLA-A24(+) patients with synovial sarcoma. J Immunol 169: 1611-1618, 2002.

85. Worley BS, van den Broeke LT, Goletz TJ, Pendleton CD, Daschbach EM, Thomas EK, Marincola FM, Helman LJ and Berzofsky JA: Antigenicity of fusion proteins from sarcomaassociated chromosomal translocations. Cancer Res 61: 6868-6875, 2001.

86. Hsu H, Lacey DL, Dunstan CR, Solovyev I, Colombero A, Timms E, Tan HL, Elliott G, Kelley MJ, Sarosi I, Wang L, Xia XZ, Elliott R, Chiu L, Black T, Scully S, Capparelli C, Morony S, Shimamoto G, Bass MB and Boyle WJ: Tumor necrosis factor receptor family member RANK mediates osteoclast differentiation and activation induced by osteoprotegerin ligand. Proc Natl Acad Sci USA 96: 3540-3545, 1999.

87. Lacey DL, Timms E, Tan HL, Kelley MJ, Dunstan CR, Burgess T, Elliott R, Colombero A, Elliott G, Scully S, Hsu H, Sullivan J, Hawkins N, Davy E, Capparelli C, Eli A, Qian YX, Kaufman S, Sarosi I, Shalhoub V, Senaldi G, Guo J, Delaney J and Boyle WJ: Osteoprotegerin ligand is a cytokine that regulates osteoclast differentiation and activation. Cell 93: 165-176, 1998.

88. Simonet WS, Lacey DL, Dunstan CR, Kelley M, Chang MS, Luthy R, Nguyen HQ, Wooden S, Bennett L, Boone T, Shimamoto G, De Rose M, Elliott R, Colombero A, Tan HL, Trail G, Sullivan J, Davy E, Bucay N, Renshaw-Gegg L, Hughes TM, Hill D, Pattison W, Campbell P, Sander S, Van G, Tarpley J, Derby P, Lee R and Boyle WJ: Osteoprotegerin: a novel secreted protein involved in the regulation of bone density. Cell 89: 309-319, 1997.

89. Tsuda E, Goto M, Mochizuki S, Yano K, Kobayashi F, Morinaga $\mathrm{T}$ and Higashio $\mathrm{K}$ : Isolation of a novel cytokine from human fibroblasts that specifically inhibits osteoclastogenesis. Biochem Biophys Res Commun 234: 137-142, 1997.

90. Yasuda H, Shima N, Nakagawa N, Yamaguchi K, Kinosaki M, Mochizuki S, Tomoyasu A, Yano K, Goto M, Murakami A, Tsuda E, Morinaga T, Higashio K, Udagawa N, Takahashi N and Suda T: Osteoclast differentiation factor is a ligand for osteoprotegerin/osteoclastogenesis-inhibitory factor and is identical to TRANCE/RANKL. Proc Natl Acad Sci USA 95: 3597-3602, 1998

91. Grimaud E, Soubigou L, Couillaud S, Coipeau P, Moreau A, Passuti N, Gouin F, Redini F and Heymann D: Receptor activator of nuclear factor kappaB ligand (RANKL)/osteoprotegerin (OPG) ratio is increased in severe osteolysis. Am J Pathol 163: 2021-2031, 2003.

92. Hofbauer LC, Dunstan CR, Spelsberg TC, Riggs BL and Khosla S: Osteoprotegerin production by human osteoblast lineage cells is stimulated by vitamin $\mathrm{D}$, bone morphogenetic protein-2, and cytokines. Biochem Biophys Res Commun 250: 776-781, 1998.

93. Hofbauer LC, Gori F, Riggs BL, Lacey DL, Dunstan CR, Spelsberg TC and Khosla S: Stimulation of osteoprotegerin ligand and inhibition of osteoprotegerin production by glucocorticoids in human osteoblastic lineage cells: potential paracrine mechanisms of glucocorticoid-induced osteoporosis. Endocrinology 140: 4382-4389, 1999. 
94. Bhatia P, Leach RJ, Roodman GD, et al: Loss of RANKL, a TNF-alpha ligand family member, in sporadic osteosarcoma. J Bone Miner Res 14 (Suppl 1): F037, 1999.

95. Wittrant Y, Theoleyre S, Chipoy C, Padrines M, Blanchard F, Heymann D and Redini F: RANKL/RANK/OPG: new therapeutic targets in bone tumours and associated osteolysis. Biochim Biophys Acta 1704: 49-57, 2004.

96. Honore P, Luger NM, Sabino MA, Schwei MJ, Rogers SD Mach DB, O'keefe PF, Ramnaraine ML, Clohisy DR and Mantyh PW: Osteoprotegerin blocks bone cancer-induced skeletal destruction, skeletal pain and pain-related neurochemical reorganization of the spinal cord. Nat Med 6: 521-528, 2000.

97. Wong BR, Josien R, Lee SY, Sauter B, Li HL, Steinman RM and Choi Y: TRANCE (tumor necrosis factor (TNF)-related activation-induced cytokine), a new TNF family member predominantly expressed in T cells, is a dendritic cell-specific survival factor. J Exp Med 186: 2075-2080, 1997.

98. Anderson DM, Maraskovsky E, Billingsley WL, Dougall WC, Tometsko ME, Roux ER, Teepe MC, Du Bose RF, Cosman D and Galibert L: A homologue of the TNF receptor and its ligand enhance T-cell growth and dendritic-cell function. Nature 390: $175-179,1997$.
99.Emery JG, McDonnell P, Burke MB, Deen KC, Lyn S, Silverman C, Dul E, Appelbaum ER, Eichman C, DiPrinzio R, Dodds RA, James IE, Rosenberg M, Lee JC and Young PR: Osteoprotegerin is a receptor for the cytotoxic ligand TRAIL. J Biol Chem 273: 14363-14367, 1998.

100. Nyambo R, Cross N, Lippitt J, Holen I, Bryden G, Hamdy FC and Eaton CL: Human bone marrow stromal cells protect prostate cancer cells from TRAIL-induced apoptosis. J Bone Miner Res 19: 1712-1721, 2004.

101. Heymann D, Ory B, Gouin F, Green JR and Redini F: Bisphosphonates: new therapeutic agents for the treatment of bone tumors. Trends Mol Med 10: 337-343, 2004.

102. Sanders JM, Ghosh S, Chan JM, Meints G, Wang H, Raker AM, Song Y, Colantino A, Burzynska A, Kafarski P, Morita CT and Oldfield E: Quantitative structure-activity relationships for gammadelta $\mathrm{T}$ cell activation by bisphosphonates. J Med Chem 47: 375-384, 2004. 